\title{
A MIGRÁCIÓ MEGÍTÉLÉSE A FELSŐOKTATÁSBAN RÉSZT VEVŐ HALLGATÓK VÉLEMÉNYE ALAPJÁN
}

A szerzők kutatási célkitűzése, hogy megvizsgálják a napjainkban megfigyelhető nagyarányú népességvándorlással kapcsolatos eseményeket, azok kiváltó okát és prediktív hatását a felsőoktatásban tanuló egyetemi hallgatók, doktoranduszok által felállított és képviselt attitűdjein keresztül. A megkérdezettek csoportját, azaz a mintát, 425 fő a magyar felsőoktatási intézményekben nappali tagozatos alapszakon, mesterszakon és doktori képzésben részt vevő hallgató képezte. $A$ megkérdezett mintán belül faktoranalízis segítségével kimutatható volt, hogy minél magasabb szintű képzésen tanulnak az egyes hallgatók, azaz minél magasabb a legnagyobb iskolai végzettségük, annál nagyobb lesz körükben azok száma, akik toleránsan viselkednek a migrációs jelenséggel kapcsolatban. Meglepő lehet, hogy a nemzetközi élettapasztalattal is rendelkező válaszadók kevésbé befogadóak a hasonló tapasztalatokkal nem rendelkező társaikhoz képest. Azt is megállapították, hogy a válaszadók munkatapasztalata jelentősen befolyásolja a befogadó attitűd meglétét vagy hiányát. A sikeres munkaerő-piaci integráció egyik kulcsa a megfelelő iskolai végzettség. A válaszadók is jelentőséget tulajdonítanak a migránsok legnagyobb iskolai végzettségének. A másik fontos szempont ugyanakkor a nyelvismeret: általános vélekedés, hogy legalább társalgási szintű magyar nyelvismeret hiányában aligha érhetnek el munkavállalói sikereket a migránsok. Mindez azért is érdemel kiemelést, mert a migráció társadalmi megítélését befolyásolja a válaszadók gazdasági helyzete: a jobb körülmények között élő válaszadók kevésbé látják veszélyesnek a migrációt, mint a rosszabb gazdasági helyzetben élő társaik.

Végzetül a migráció médiareprezentációjával kapcsolatban egyértelműen megállapítható, hogy a migráció belföldi megítélésében a hazai média szerepe kiemelt jelentőségű.

Kulcsszavak: migráció, felsőoktatás, munkaerőpiac, diszkrimináció

$\mathrm{Az}$ utóbbi években hazánkban kiemelkedő társadalmi érdeklődés kísérte a migrációt, azon belül is elsősorban az Európa, az Európai Unió irányába irányuló migráció jelenségét. A tömegesen megjelenő migránsok felkavarták a hazai politika állóvizét, a hétköznapi közbeszéd minden szintjén megjelentek az országba érkező migránsok. Ezt jól jelképezi, hogy az Index.hu, Magyarország egyik legnépszerübb internetes hírportálja által üzemeltetett mappastruktúrában csak a ,Kerítés a magyar határon” gyüjteményben olvasható 253 cikk 2015 júniusa és 2017 szeptembere között, a „Menekültek Németországban" mappában 145 cikk 2015 májusa és 2017 szeptembere között, a „Népszavazás a menekültbetelepítési kvóta ellen" mappában pedig további 239 cikk található, amelyek 2016 februárja és 2017 februárja között jelentek meg a híroldalon (Index, 2017). A téma aktualitását már az is jól jelzi, hogy három különálló kategóriában jelennek meg a híroldal cikkei, amelyek három eltérő aspektus szerint foglalkoznak a témával.

A migrációval összefüggésben a közérdeklődés növekedése nem kis részben a kiemelkedően aktív kormányzati kommunikációnak volt köszönhető, amelynek sikerült ezt a témát a közbeszéd középpontjába állítania annak dacára, hogy 2015 elött nem volt különösebben érzékelhetö érdeklődés a migráció iránt, ráadásul a hazánkba érkező migránsok tranzitországnak tekintik hazánkat, és lehetôségeikhez mérten tovább kívánnak utazni valamelyik nyugat-európai uniós tagállamba, illetve a tartós letelepedés céljával az országba érkezők döntő hányada határon túli magyar (Janky, 2016). A migráció hazai médiareprezentációját alapjaiban határozta meg, hogy a tárgykörben a Kormány Nemzeti Konzultációt is hirdetett (Kiss, 2016), amelynek eredményei később is hivatkozási alapul szolgálhattak a különböző jogi és politikai döntésekhez. A menekültek és menedékkérők száma az elmúlt években jelentösen megnövekedett a fejlett demokratikus országokban, ez a folyamat pedig a kutatók figyelmét is e rendkívül komplex társadalmi folyamat felé irányította. Kijelenthető, hogy a migráció gyakorlatilag egyidős az emberiséggel, így korántsem tekinthető új jelenségnek (Hautzinger et al., 2014).

A nyugat-európai országokba, azon belül is elsősorban Németországba irányuló migráció 2015 után olyan intenzívvé vált, hogy a hagyományos állami segítőrendszer mellett nagy felelősség hárult a különböző jótékonysági és karitatív szervezetekre is. Az önkéntesek ezekben az esetekben az állami szerepvállalással párhuzamosan, vagy azt mintegy helyettesítve jártak el annak érdekében, hogy élhető körülményeket biztosítsanak az újonnan érkezőknek (Braun, 2017). Természetesen a civil szervezetek sem képesek önerőből elvégezni a felmerülő feladatokat, tevékenységükhöz gyakorta a különböző közösségi médiumokon keresztül próbálnak támogatást gyüjteni. Itt pedig építhetnek a közösségi média felhasználóinak, köztük is az úgynevezett impulzusadományozóknak a segítségére, támogatására. Ezek az adakozók eltérő okok miatt döntenek úgy, hogy valamilyen - jellemzően pénzügyi - támogatás formájában segítséget nyújtanak egyes civil szerve- 
zetek müködéséhez. Ilyen motiváció lehet a büntudat, a boldogság, a szimpátia vagy az empátia (Hubert, 2017). A migráció iránt mutatkozó kutatói érdeklődés remek példája Tóth (2015) cikke, aki nemcsak a migráció és a muszlimok médiareprezentációjának a szociológiai tudományok területén született cikkek feldolgozását végezte el, hanem általános média-szerepértelmezést is adott azzal a kijelentésével, hogy a különböző médiumok a migráció és a muzulmán vallás megítélése szempontjából kulcsszerepet játszanak. A kutatás szerint leggyakrabban a média tartalomra és közönségre gyakorolt hatását emelik ki a muszlimok és a migráció médiareprezentációjának vizsgálatával foglalkozó szociológiai tárgyú cikkek. Ugyanakkor csak az elmúlt évtizedekben kezdtek el nagyobb hullámokban vándorolni az emberek más országokba, így a migrációt vizsgáló kutatások is a közelmúltban kaptak kiemelt figyelmet (Hooghe et al., 2008). Mint azt Máté et al. (2016) cikkében is bemutatja, a migrációs hatások vizsgálatának egyik legfontosabb tárgyköre a gazdasági elemzések között a migráció hatása a bevándorlás által érintett célországok lakóinak jövedelmére. A cikk összefoglalása szerint a migránsok jelenléte nem gyakorol jelentősebb hatást az ott született állampolgárok átlagos jövedelmére.

A kutatás célja a felsőoktatásban tanuló hallgatók és doktoranduszok körében felmérni a migráció hatásait, a jelenségről alkotott véleményeket. Meggyőződésünk szerint a jövő társadalmának jellegzetességeit jelentősen befolyásolja a fiatal diplomások, értelmiségiek migrációval kapcsolatos attitűdje. Kutatásunkban mindenkit egységesen migránsként kezeltünk, nem tettünk különbséget gazdasági és jogi menekültek, menedékkérők vagy más jogi kategóriák érintettjei között. A menekültstátusszal kapcsolatos legfontosabb jogszabály továbbra is az 1951. évi genfi egyezményeket kihirdető magyarországi jogszabály, az 1989. évi 15. tvr. A hivatkozott jogszabály 1. cikk A pont (2) bekezdés értelmében menekültnek tekinthetö mindaz, aki , 1951. január 1. elött történt események következtében faji, vallási okok, nemzeti hovatartozása, illetve meghatározott társadalmi csoporthoz való tartozása, avagy politikai meggyözödése miatti üldözéstől való megalapozott félelme miatt az állampolgársága szerinti országon kívül tartózkodik, és nem tudja, vagy az üldözéstől való vélelmében nem kívánja annak az országnak a védelmét igénybe venni; vagy aki állampolgársággal nem rendelkezve és korábbi szokásos tartózkodási helyén kivül tartózkodva ilyen események következtében nem tud, vagy az üldözéstöl való félelmében nem akar oda visszatérni”. Az illegális bevándorlók és a menekültek elválasztása történelmileg is érdekes folyamat volt, amelynek során kialakultak a menekültek és a bevándorlók jogi kategóriái is (Kránitz, 2016). A felmérés hangsúlyos eleme a migránsok médiareprezentációjáról alkotott vélemények elemzése volt, ami nem tette lehetővé a hétköznapi közbeszéd migrációs fogalomtáránál bonyolultabb meghatározások alkalmazását.

Hautzinger et al. (2014) a migrációs jelenségeket több szempont alapján is osztályozza. Ennek megfelelően megkülönböztethető külső és belső (országon belüli) migráció, meghatározható az ellentétes irányú kivándorlás és bevándorlás. A vándorlók létszáma alapján egyéni és csoportos migráció is elkülöníthető, a kiváltó okok szerint pedig önkéntes migráció és menekülés is ismert - ez utóbbi kiváltója általában valamilyen üldözés, háború, erőszak, illetve ezek közvetlen fenyegetése. A migráció időtartama alapján ismert időszakos és tartós migráció, míg a jelenség jellege alapján megkülönböztethető gazdasági, politikai, ökológiai és kulturális migráció. A migráció szabályozottsága alapján ismerünk ellenőrzött és ellenőrizetlen migrációt is. Jelen cikkben mindenképpen a nemzetközi migrációs jelenségekkel foglalkozunk, a jelenség további lehatárolása azonban nem valósítható meg, csak a kitöltött kérdöív kérdéssorának ismeretében.

A migráció kiváltó okai igen változatosak lehetnek. A gazdaságtudomány bevett elmélete, a push-pull modell szerint a migráció folyamatos áramlást jelent, vagyis a gazdaságilag kevésbé sikeres, szegényebb területeken meglévő népességtöbbletet a szegényebb gazdaság kitaszítja magából, amelyet a sikeresebb gazdaságok, a gazdag országok magukhoz vonzanak. Ez a modell jól szemlélteti a már kialakult migrációs folyamatok müködését, azonban nem ad választ arra kérdésre, hogy miért csak egyes szegény régiók esetében alakul ki a migráció. Erre magyarázatot jelenthet a nemzetközi migránshálózatok személyközi kapcsolati rendszere, amely a korábbi (sikeres) migránsok és a kivándorlást tervező korábbi honfitársaik kapcsolati hálójaként azonosítható (Ekéné Zamárdi - Dövényi, 2010). Jelen esetben a migráció egyik, de korántsem egyedüli kiváltó oka a Szíriában és annak környezetében dúló háború volt.

Az elemzés célja - a negatív megítéléshez kapcsolódóan - tehát annak bemutatása, hogy mely gazdasági és nem gazdasági tényezők határozzák meg a migráció minőségi megítélését, illetve hogy a két fő tényezőcsoport közül melyik a dominánsabb. A pozitív irányú és a migráció támogatását szorgalmazó válaszok takarják a gazdaság és a szociális élet migráció hatására megvalósuló színvonalának fejlödését. A kutatás során a gazdálkodás- és szervezéstudományok, az emberierőforrás-menedzsment, a szociológia, továbbá a kommunikáció- és médiatudomány bevett kutatási módszereit alkalmazva a felsőoktatásban tanuló hallgatók migrációval kapcsolatos véleményeit elemeztük.

\section{Kutatási hipotézisek}

A kutatás során az alábbi hipotézisek teljesítését vizsgáltuk.

A H1 hipotézis szerint a válaszadók - felsőoktatási hallgatók, akik a magas szakképzettségüek csoportját alkotják - saját érdekeiket figyelembe véve elutasítóak az azonos képzettségűekkel szemben, mivel a hazai munkaerőpiacon e bevándorlók jelentenének konkurenciát számukra.

A, Feltételezésünk szerint a magasan szakképzett bevándorlók és a külföldi felsőoktatási hallgatók nem jelentenek veszélyt az általunk megkérdezett hallgatói csoportok elhelyezkedésére, sőt inkább pozitív hatást gyakorolhatnak a hazai gazdaságra. 
B, A hazai lakosság eltérő társadalmi osztályai és ezek különböző jövedelemszintjei eltérően ítélik meg azt, hogy a különböző szakképzettséggel rendelkezö külföldi munkavállalók milyen hatással vannak a magyar munkaerö-piaci versenyre.

$\mathrm{C}, \mathrm{Az}$ egyéni döntéseket az is meghatározza, hogy a válaszadók mennyire ítélik veszélyesnek a bevándorlás gazdaság és szociális ellátórendszerre kifejtett hatását hosszú távon.

H2 hipotézis: A nem gazdasági jellegü okok, mint például a kulturális és etnikai feszültségektől való félelem, a hírforrások és a bevándorlók eltérő szempontok szerint történő megkülönböztetése jelentősen növelik az anti-migrációs hangulatot.

H3 hipotézis: A különböző hírforrások (a hazai közszolgálati és kereskedelmi TV-k, rádiók, a külföldi média, az internetes sajtó, a közösségi média) és azok követésének gyakorisága eltérö hatást gyakorol a bevándorlás megítélésére.

\section{Anyag és módszer}

Primer kutatásunk során a magyarországi Hallgatói Önkormányzatok Országos Konferenciája (HÖOK) és a Doktoranduszok Országos Szövetsége (DOSZ) segítségével keresztmetszeti felmérést végeztünk az interneten keresztül 2017 januárjában. A részvétel önkéntes és anonim volt, de törekedtünk az országos reprezentativitásra (1. táblázat). A mintavételi keretet (alapsokaságot) a magyar felsőoktatási intézményekben nappali tagozatos alapszakon, mesterszakon és doktori képzésben részt vevő hallgatók és doktoranduszok képezték (HÖOK- vagy DOSZ-tagok). A minta összeállításánál figyelembe vettük azokat az előzetes tanulmányokat, amelyek szerint a magasabb iskolai végzettséggel rendelkező csoportok alapvetően kedvezőbben és pozitívabb érvekkel értékelik a bevándorlást és az idegen országban való letelepedést, munkavállalást (például Hainmueller - Hiscox, 2010).

1. táblázat

A minta és az országos arányok alakulása

\begin{tabular}{|l|l|c|c|}
\hline \multicolumn{2}{|c|}{} & Felmérés \% & Országos \%** \\
\hline \multicolumn{2}{|l|}{ Kor (év) } & $21,10(2,13)^{*}$ & \\
\hline \multirow{2}{*}{ Nem } & Nő & 56,00 & 56,40 \\
\cline { 2 - 4 } & Férfi & 44,00 & 43,60 \\
\hline \multirow{2}{*}{\begin{tabular}{l} 
Lakhely \\
\multirow{2}{*}{$\begin{array}{l}\text { Legmagagas } \\
\text { végzettség }\end{array}$}
\end{tabular}} & Vidék & 37,20 & 30,50 \\
\cline { 2 - 4 } & Város & 62,80 & 69,50 \\
\hline \multirow{2}{*}{$\begin{array}{l}\text { Jövedelem- } \\
\text { szint }\end{array}$} & Érettségi & 68,50 & 73,00 \\
\cline { 2 - 4 } & BSc/BA & 27,50 & 25,00 \\
\cline { 2 - 4 } & MSc/MA/PhD & 4,00 & 2,00 \\
\cline { 2 - 4 } & Átlag alatt & 23,00 & \\
\cline { 2 - 4 } & Átlagos & 58,80 & \\
\hline
\end{tabular}

* Átlag (Szórás)

**Központi Statisztikai Hivatal (2011), Szabó (2015)

Forrás: saját számítás
A kérdőív három kérdéscsoportból állt, nevezetesen a szocioökonómiai kérdések, a gazdaságot érintő kérdések és nem gazdasági jellegü kérdések is. A hatvan kérdést tartalmazó kérdőívet 438 fö töltötte ki.

\section{A vizsgált minta szocioökonómiai jellemzői}

Szocioökonómiai jellemzők alatt mindenekelőtt a megkérdezettek életkorát, legmagasabb iskolai végzettségét és társadalmi osztály szerinti életszínvonalát értjük a jövedelem alapján, lakhelyük szerinti bontásban. Az elemzés szempontjából figyelembe vettük a munkaerőpiac már aktív tagjainak arányát is, ami a hallgatók esetében komoly hatást gyakorolhat általános világképük fejlődésére és személyiségük kialakulására, ugyanakkor a nappali munkarend szerint tanulmányokat folytató hallgatók körében továbbra sem egyértelmü, hogy vállalnak-e munkát. Ezen felül fontosnak tartottuk megvizsgálni a válaszadók külföldi utazásról és idegen országok állampolgárairól szerzett általános tapasztalatait (Oláh et al., 2017).

A 438 válaszadóból 425 fö válasza bizonyult értékelhetőnek. Annak ellenére, hogy a felmérés során törekedtünk arra, hogy a megkérdezettek jól reprezentálják a hazai felsőoktatásban tanuló nappali hallgatókat, de a mintánkat a Központi Statisztikai Hivatal (KSH) által közölt 2011. évi adataival összevetve kijelenthető, hogy a vizsgálat során megkérdezett válaszadók csak a nemek esetében reprezentálják megfelelően az országos arányokat. A városi és vidéki diákok aránya 2011-ben 69,5\% és 30,5\% volt (Központi Statisztikai Hivatal, 2017a), az általunk vizsgált minta tagjainak esetében ettől eltért a városokban és a falvakban élő diákok aránya (62,8\% és $37,2 \%)\left(\chi^{2}=8,688 ; \mathrm{Szf}=1 ; \mathrm{p}=0,003\right)$ (1. táblázat). A nők és férfiak felsőoktatásban megfigyelhető megoszlása reprezentatívan ábrázolja az országos átlagot $\left(\chi^{2}=0,038\right.$; $\mathrm{Szf}=1$; $\mathrm{p}=0,845)$. A KSH jelentése alapján a felsőoktatásban 2011ben a nők és férfiak aránya 56,4\% és 43,6\% volt (Központi Statisztikai Hivatal, 2017b), amíg a mintánkban 56\%-os női részvételi arányt mértünk a férfiak 44\%-os részvételi arányával szemben.

A legmagasabb iskolai végzettséggel rendelkezők megoszlása során az érettségi bizonyítvány, a BSc, BA-oklevél és az MSc, MA-diploma megszerzését vizsgáltuk és vetettük össze a Központi Statisztikai Hivatal különböző szintü végzettségek megszerzésére vonatkozó adatközlésével. Az Aktív Fiatalok Magyarországon Kutatócsoport 2015 áprilisában megjelent kutatása a magyar nappali tagozatos hallgatók közül az alapképzésre (BA/BSc), a mesterképzésre (MA/MSc) és a doktori képzésre (PhD/DLA) járó hallgatókat vizsgálta. A 2015. évi felmérés szerint hallgatók 73\%-a járt alapképzésre, 25\%-a mesterképzésre, míg 2\%-uk doktoranduszhallgató (Szabó, 2015; Központi Statisztikai Hivatal, 2017c; Központi Statisztika Hivatal, 2017d). A saját minta arányai ettől kismértékben eltértek - ahol a legmagasabb iskolai végzettségböl és az aktív hallgatói jogviszonyból számoltunk megoszlást -, mivel a hallgatók 68,5\%-a alapszakon, 27,5\%-a mesterszakon tanult, 4\%-a pedig doktori képzésen vett részt $\left(\chi^{2}=9,417\right.$; $\mathrm{Szf}=2 ; \mathrm{p}=0,009)$. A mintavétel eredményével kapcsolat- 
ban ugyanakkor meg kell említeni azt is, hogy a reprezentativitás a vizsgált szempontok szerint annyiban érdemel említést, amennyiben az adott szempontok összefüggnek a vizsgált kérdésekkel.

A leíró statisztikai mutatók mellett két független mintás t-próbát, egytényezős varianciaanalízist, faktorelemzést és bináris logisztikus regressziós modellt számítottunk az SPSS 23.0 szoftver segítségével.

Abban az esetben, amikor az eltérő szocioökonómiai csoportok válaszainál két kategóriát különítettünk el, két független mintás t-próbát alkalmaztunk. A kettőnél több kategória esetében egytényezős varianciaanalízist használtunk, a páronkénti összehasonlításra pedig a Tukey post hoc tesztet alkalmaztuk. A kérdések közös csoportokba sorolására faktorelemzést alkalmaztunk annak vizsgálatára, hogy mely kérdések kerültek egy csoportba. Ezeket a faktorokat a faktort kialakító kérdések alapján neveztük el. Bináris logisztikus regressziós modell segítségével megállapítottuk, hogy mely tényezők határozzák meg szignifikánsan a migráció elfogadását vagy elutasítását.

\section{Eredmények}

\section{A migráció megítélését befolyásoló nem gazdasági tényezők}

Az Európai Unióban megkérdezett lakosság 58\%-a úgy véli, hogy az állami beavatkozások negatív hatással vannak a mindennapi életükre. Országos adatokat tekintve Magyarország, Portugália, Szlovénia az Egyesült Királyság és Görögország lakosai a legkevésbé elégedettek ezzel a helyzettel, és ebből következően nem meglepő, hogy a portugál és magyar állampolgárok a legkételkedőbbek saját jövőjüket illetően (European Commission, 2008).

Ennek felmérését az elkészített kérdőívben is elvégeztük, ugyanis az általános megelégedettség szintjére és a migráció közeli jövőbeni alakulására kérdeztünk rá. Számos korábbi tanulmány azt sugallja, hogy a bevándorlást ellenző vélemények első számú mozgatórugói a nem gazdasági jellegű aggályok, azon belül a kulturális és etnikai feszültségektől való félelem, ami a hazai és migráns csoportok között kedvezötlen esetben kialakulhat (Citrin et al., 1997; Lahav, 2004; Bauer et al., 2000; Hainmueller - Hiscox, 2010). A befogadó társadalom félelmei mellett azt is ki kell emelni, hogy az Európába vagy azon belül Magyarországra érkező bevándorlókat is érheti úgynevezett kulturális sokk új élethelyzetükkel összefüggésben. Bogáromi - Malota (2017) leírása szerint a kulturális sokk alatt fizikai és pszichés alkalmazkodási nehézségeket érthetünk, amelyekkel a külföldre érkezők a célország kultúrájával, társadalmával való kapcsolatba lépés idején szembesülnek. Ennek legfontosabb oka, hogy a külföldi elveszíti azokat a fix pontjait a személyközi és társas kommunikációban, amelyek mentén értelmezni képes az őt körülvevő világ eseményeit, ez pedig erősen kihat saját személyes identitására is.

A konszenzus hiányának - egyes emberek miért támogatják, míg mások miért ellenzik a bevándorlást - egyik oka, hogy az egyéni véleményalkotásból leszürhető adatok kevésbé alkalmasak - angol megfogalmazásban „,ill-suited" - elméleti összefüggések tesztelésére és a kérdésre adott válasz interpretációjára. A főleg gazdasági szempontokat vizsgáló tanulmányok általában egyensúlyi modell felállítását preferálják annak megbecsülésére, hogy a hazai lakosság - akik eltérően rangsorolják a fejlődés feltételeit és eltérő jövedelemmel rendelkeznek - hogyan vélekedik a különböző szakképzettségü migránsokról (Facchini - Mayda, 2009; Hainmueller - Hiscox, 2010).

A migránsok vagy bevándorlók sikeres integrációjára nem lehet egy egységesen sikeres cselekvési tervet megalkotni. Gödri (2016) szerint a bevándorlók integrációja földrajzi területenként és kohorszonként rendkívül nagy eltéréseket mutat. Az integráció sikerességét számos szempont befolyásolja, amelyek közül célszerü kiemelni a különböző gazdasági nézőpontokat. Komoly hatást gyakorolhat ugyanakkor a migrációt kiváltó hatások különbözősége (például háború elől menekülőkkel szemben szolidaritás alakulhat ki), de a bevándorlás sikerét az adott nemzeti csoport általános elfogadottsága és helyzete is befolyásolja. A korábbi kutatások eredményeinek ellenőrzéséhez indokolt megvizsgálni, hogy a bevándorlásellenes viselkedés miért nem értelmezhető a migráció gazdasági hatásain keresztül.

Az Amerikai Egyesült Államokban végzett egyik nemzeti felmérésben a szerzők véletlenszerűen kiválasztott válaszadókat kértek fel arra, hogy értékeljék a bevándorlókat különböző képzettségi szintjeik alapján. Ily módon elfogulatlan eredményt kaptak az attitüdök eloszlásáról a magasan képzett és a kevésbé képzett bevándorlókra vonatkozóan. Az ilyen típusú összehasonlítás és a válaszadók tulajdonságainak eltérése teszi lehetővé, hogy az elméleti előrejelzések modelljeit a gazdasági megfontolások attitűdre gyakorolt befolyásolásával is tesztelhessük (Hainmueller - Hiscox, 2010). A társadalmi-kulturális kontextus ismerete nélkül nem érthető meg az ember szociokulturálisan meghatározott attitüdje azokhoz a különböző helyzetekhez kapcsolódóan, amelyekbe kerülhet (Lajos, 2016). A kulturális kompetenciák hiánya mellett - amelyek fennállnak a bevándorlás során - még említést érdemel a közösen beszélt nyelv hiánya okozta nehézség, illetve annak a lehetőségnek a hiánya, hogy a migráns saját anyanyelvén fejezhesse ki gondolatait.

A válaszadók 72,7\%-a legalább 3-ra értékelte azt a kérdést, hogy a bevándorlók esetében figyelembe kell venni a kulturális hátterüket, mivel azok ismeretében megfelelő szakembereket, szakfordítókat alkalmazva elősegíthető a migráció folyamata és az integráció (2. táblázat). $75 \%$-uk ezen felül félti a hazai kultúra fennmaradását és integritását, mert a külföldi kultúrák keveredése, a multikulturalizmus és a transznacionalizmus árt az ország társadalmának. A transznacionalizmus fogalmát a migrációkutatásban olyan folyamatokként definiálják, amelyek segítségével a bevándorlók társadalmi kötelékeket építenek ki a kibocsátó és a befogadó országok között (Schiller et al., 1992). A nyelvismeret szintén kulcsfontosságú kérdés, a mintából vett felmérés alapján a válaszadók 91,2\%-a közepesen vagy annál fontosabbnak tartotta a hazai nyelv legalább társalgási szintű ismeretét. Ehhez hasonlóan az 
értékelhető válaszadók 94,8\%-a kiemelt kérdésként kezelte a hazai törvények és jogi szabályozások betartását. A válaszadók több mint háromnegyede közösségi szinten egységes nézetekkel rendelkezik a nem gazdasági jellegü bevándorlást érintő kérdésekben (Oláh et al., 2017). A nyelvismeret szükségességét más kutatások is kimutatták nemhogy a migráció, a harmadik országból érkező bevándorlók esetében, de még a nemzetközi nagyvállalatok topmenedzsereinek körében is. Kimutatások szerint a helyi - jellemzően idősebb - kollégákkal való kapcsolattartást, a munkavégzést a fogadó ország nyelvének ismerete nagyban megkönnyíti még olyan nyugat-európai országokban is, mint például Hollandia (Nagy - Primecz, 2014).

2. táblázat

\section{Válaszadók véleményének megoszlása a migráció okairól}

\begin{tabular}{|l|c|c|c|c|c|}
\hline \multirow{2}{*}{ Likert-skála } & $\mathbf{1}$ & $\mathbf{2}$ & $\mathbf{3}$ & $\mathbf{4}$ & $\mathbf{5}$ \\
\cline { 2 - 6 } & $\mathbf{N} \%$ & $\mathbf{N} \%$ & $\mathbf{N} \%$ & $\mathbf{N} \%$ & $\mathbf{N} \%$ \\
\hline $\begin{array}{l}\text { Kulturális } \\
\text { háttér alapján } \\
\text { történó megkü- } \\
\text { lönböztetés }\end{array}$ & $10,40 \%$ & $16,90 \%$ & $28,70 \%$ & $29,60 \%$ & $14,40 \%$ \\
\hline $\begin{array}{l}\text { Nyelvtudás } \\
\text { fontossága }\end{array}$ & $3,60 \%$ & $5,20 \%$ & $20,40 \%$ & $35,90 \%$ & $34,90 \%$ \\
\hline $\begin{array}{l}\text { Törvények tisz- } \\
\text { teletben tartása } \\
\text { és betartása }\end{array}$ & $2,40 \%$ & $2,90 \%$ & $14,50 \%$ & $21,60 \%$ & $58,70 \%$ \\
\hline
\end{tabular}

Forrás: saját számítás, 2017

A kérdőívekben feltett kérdések többségét 1-től 5-ig terjedő, úgynevezett Likert-skálán mértük. Az 1-es érték az egyetértés feltételeit vizsgáló kérdések esetében a teljes egyet nem értés szöveges formában prezentált állításnak felelt meg, míg az 5. érték a teljes egyetértést tükrözte. Bizonyos kérdéseket 1-től 10-ig terjedő Likert típusú skálán értékeltünk a megoszlás alaposabb vizsgálata érdekében. A kérdőív többi része kategorikus volt (3. és 4. táblázat). A kérdőív megbízhatóságát a Cronbach-alfa tesztje igazolta. Az elért eredményeket vizsgálva a mérés eszközeinek megbízhatósága elegendőnek tekinthető (4. táblázat). A konstrukció érvényességét faktorelemzéssel igazoltuk a faktorok Varimax rotációjának használatával, amely a legelterjedtebb módszer a rotációs eljárások közül (Savov et al., 2017). A faktorok Varimax forgatása egy ortogonális forgatási módszer, amely minimálisra csökkenti a tényezők nagyterhelésü változóinak számát, ezáltal növelve a tényezők értelmezhetőségét (Field, 2013). A faktorelemzés alkalmazhatóságát a Kaiser-Meyer-Olkin mintavételi megfelelőség mérése (KMO-teszt) és a Bartlett-féle gömbölyűségi teszt (Pop - Pelau, 2017) igazolja. Mindkét vizsgálati módszer eredménye kielégítő volt (Bartlett-teszt: $\mathrm{p}<0,001, \mathrm{KMO}$ teszt: 0,755). A faktorelemzés alkalmazásához szükséges feltevések teljesültek. A faktoranalízis 6 különböző háttérfaktort azonosított, amelyek összesen a teljes variancia 71,9\% -át magyarázták (3. és 4. táblázat). Mivel az azonosított tényezők teljes mértékben megfelelnek a kérdöív tartalmának, a mérési eszközök összeállításának érvényessége kielégítőnek tekinthető.
3. táblázat

\section{A migrációval kapcsolatos vélemények feltáró faktorelemzése I.}

\begin{tabular}{|c|c|c|c|c|c|}
\hline \multirow{2}{*}{ Elem } & \multirow{2}{*}{$\begin{array}{c}\text { Átlag } \\
\text { (Szórás) }\end{array}$} & \multicolumn{4}{|c|}{ Faktor } \\
\hline & & 1 & 2 & 3 & 4 \\
\hline \multicolumn{6}{|l|}{ F1: Veszélyérzet } \\
\hline $\begin{array}{l}\text { Társadalmi feszültség } \\
\text { növekedése }\end{array}$ & $4,37(0,78)$ & 0,84 & & & \\
\hline $\begin{array}{l}\text { Bünesetek számának } \\
\text { növekedése }\end{array}$ & $4,42(0,82)$ & 0,79 & & & \\
\hline $\begin{array}{l}\text { Párhuzamos társadal- } \\
\text { mak kialakulása }\end{array}$ & $4,20(0,87)$ & 0,76 & & & \\
\hline $\begin{array}{l}\text { Szélsőséges cselekede- } \\
\text { tek növekedése }\end{array}$ & $4,25(0,88)$ & 0,73 & & & \\
\hline \multicolumn{6}{|c|}{ F2: Sikeres integráció feltételei } \\
\hline $\begin{array}{l}\text { Munkavállalás és } \\
\text { szakképzettség }\end{array}$ & $3,88(0,97)$ & & 0,83 & & \\
\hline Nyelvismeret & $3,95(1,04)$ & & 0,78 & & \\
\hline Helyi kultúra elfogadása & $4,04(0,99)$ & & 0,69 & & \\
\hline $\begin{array}{l}\text { Törvények tiszteletben } \\
\text { tartása }\end{array}$ & $4,33(0,97)$ & & 0,65 & & \\
\hline \multicolumn{6}{|l|}{ F3: Hírforrások } \\
\hline Internetes sajtó & $3,10(1,14)$ & & & 0,97 & \\
\hline Közösségi média & $2,99(1,14)$ & & & 0,57 & \\
\hline Külföldi sajtó & $2,45(1,19)$ & & & 0,56 & \\
\hline \multicolumn{6}{|c|}{ F4: Bevándorlók megkülönböztethetősége } \\
\hline Együttműködés alapján & $3,64(1,20)$ & & & & 0,71 \\
\hline Szakképzettségük alapján & $3,70(1,09)$ & & & & 0,70 \\
\hline Kulturális hátterük alapján & $3,20(1,19)$ & & & & 0,68 \\
\hline \multirow{2}{*}{ Elem } & \multirow{2}{*}{$\begin{array}{c}\text { Átlag } \\
\text { (Szórás) }\end{array}$} & \multicolumn{4}{|c|}{ Faktor } \\
\hline & & 1 & 2 & 3 & 4 \\
\hline A faktorok sajátértékei & & 4,06 & 2,68 & 1,94 & 1,73 \\
\hline $\begin{array}{l}\text { Faktor által magyará- } \\
\text { zott variancia }(\%)\end{array}$ & & 22,58 & 14,87 & 10,76 & 9,63 \\
\hline Cronbach's alfa & & 0,87 & 0,85 & 0,73 & 0,76 \\
\hline
\end{tabular}

Forrás: saját számítás, 2017

4. táblázat

A migrációval kapcsolatos vélemények feltáró faktorelemzése II.

\begin{tabular}{|c|c|c|c|}
\hline \multirow{2}{*}{ Elem } & \multirow{2}{*}{$\begin{array}{l}\text { Átlag } \\
\text { (Szórás) }\end{array}$} & \multicolumn{2}{|c|}{ Faktor } \\
\hline & & 5 & 6 \\
\hline \multicolumn{4}{|c|}{ F5: A gazdaság jelen állapotával való megelégedettség } \\
\hline Egészségügy helyzetével kapcsolatosan & $9,17(1,21)$ & 0,95 & \\
\hline Oktatással kapcsolatosan & $8,50(1,37)$ & 0,52 & \\
\hline \multicolumn{4}{|l|}{$\begin{array}{l}\text { F6: Szociális és gazdasági problémák } \\
\text { felszámolása }\end{array}$} \\
\hline Társadalmi problémák felszámolása & $7,80(1,78)$ & & 0,81 \\
\hline Munkanélküliség csökkentése & $8,22(1,76)$ & & 0,70 \\
\hline \multirow{2}{*}{ Elem } & \multirow{2}{*}{ Átlag (SD) } & \multicolumn{2}{|c|}{ Faktor } \\
\hline & & 5 & 6 \\
\hline A faktorok sajátértékei & & 1,51 & 1,03 \\
\hline Faktor által magyarázott variancia (\%) & & 8,36 & 5,71 \\
\hline Cronbach's alfa & & 0,72 & 0,76 \\
\hline
\end{tabular}

Alkalmazott módszer: Maximum likelihood. Forgatási módszer: Varimax Kaiser normalizációval; KMO $=0,755$; Bartlett-teszt $\left(\chi^{2}=2751,04\right.$; p <0,001); Kommunalitások: 0,50 - 0,93; Teljes magyarázott variancia: 71,90\%; Cronbach alfa (Total): 0,$76 ; \mathrm{N}=419$.

Forrás: saját számítás, 2017 
A faktoranalízis eredményeként a kérdéseket 6 különálló csoportba sikerült elkülönítenünk (3. és 4. táblázat). Az első négy faktor (,Veszélyérzet”, ,Sikeres integráció feltételei”, „Hírforrások”, „Bevándorlók megkülönböztethetősége") nem gazdasági szempontokat jelent, míg az 5. és a 6. faktor (,A gazdaság jelen állapotával való megelégedettség”, „Szociális és gazdasági problémák felszámolása") inkább a gazdasági szempontokat foglalta magában. Az így elkülönített faktorokat felhasználtuk a bináris logit modellben azért, hogy ki lehessen mutatni a hatásukat a migráció általános elfogadásával kapcsolatban (5. táblázat). közül azok, akik dolgoznak tanulmányaik mellett vagy előtte már dolgoztak, sokkal jobban féltik az állásukat a bevándorlóktól - az elfogadás esélye mindössze 0,16-szoros -, mint azok, akik még eddig nem dolgoztak. Hasonló a helyzet azok esetében is, akik rendszeresen járnak külföldre, mivel az esély értéke ebben az esetben 0,29. Ez azt jelenti, hogy a rendszeresen külföldre utazó válaszadók kevésbé ítélik pozitívnak a migrációt, mint társaik.

Ezzel ellentétes eredményt kaptunk a külföldi baráttal rendelkező válaszadók esetében, mivel náluk 3,39-szoros a külföldiek elfogadásának az esélye azokkal szemben, akiknek nincs ilyen barátjuk. A városban lakók is sokkal

A bináris logisztikus regressziós modell változói

5. táblázat

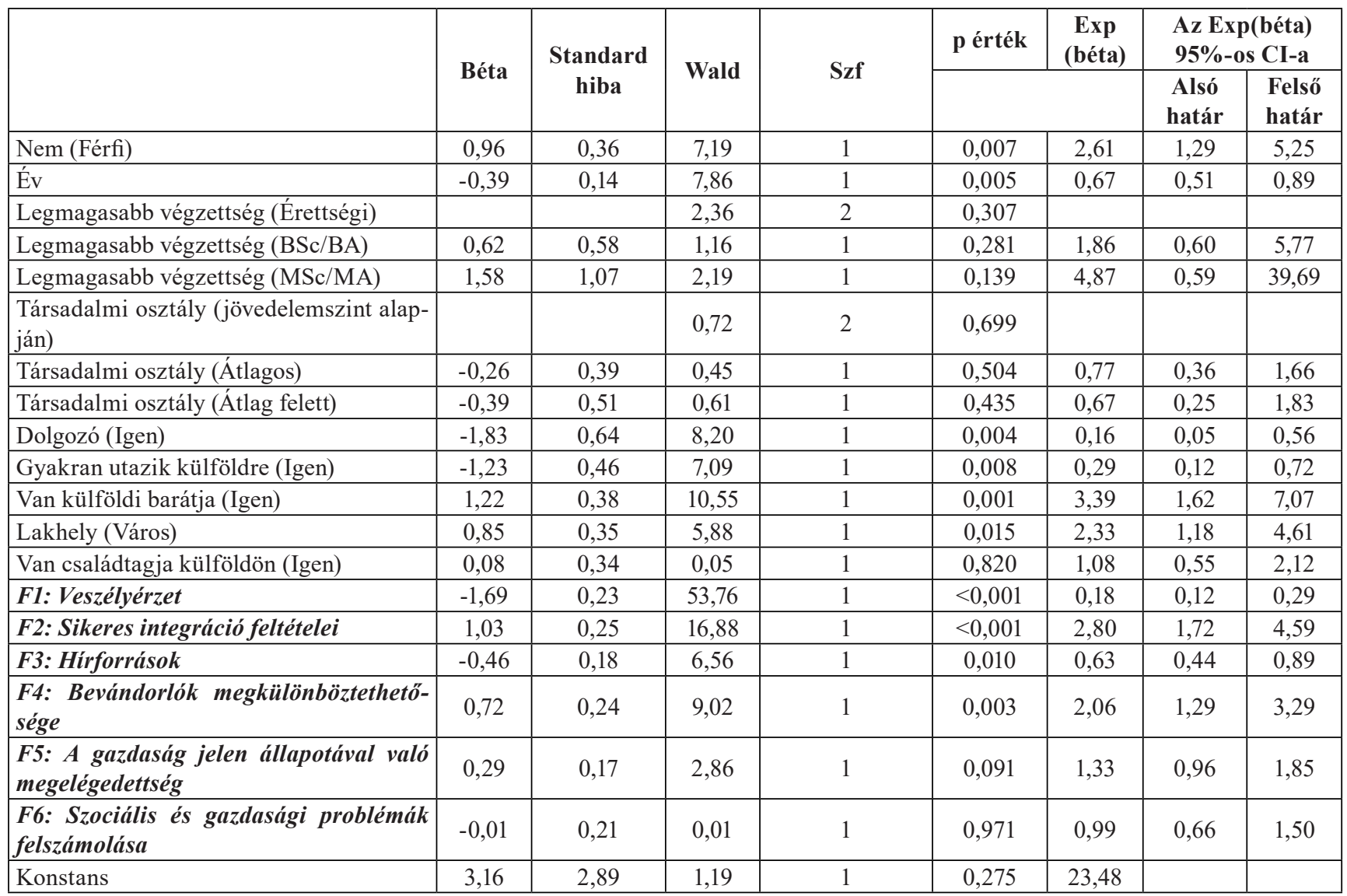

${ }^{a}$ Bináris függő változó: Összességében támogatja a migrációt (Igen/Nem); - 2 Loglikelihood érték: 247,59; Cox \& Snell pszeudo R-négyzet értéke: 0,31; Nagelkerke pszeudo R-négyzet értéke: 0,47; Khi-négyzet érték: 131,76 Forrás: saját számítás, 2017

Megfigyelhető, hogy a végzettségi szint, a társadalmi osztály, a külföldön élö hozzátartozó és a gazdasági kérdéseket magában foglaló két faktor (az 5. faktor - „A gazdaság jelen állapotával való megelégedettség” és a 6 . faktor - „Szociális és gazdasági problémák felszámolása”) hatása nem volt szignifikáns. Ugyanakkor a modellben szereplő többi tényező különböző kategóriái vagy szintjei között eltérés volt kimutatható. A nemek esetében az exponenciális beta értéke 2,606 volt, ami azt jelenti, hogy a férfiak 2,6-szeres eséllyel fogadják pozitívan a migrációt a női válaszadókhoz viszonyítva. Az életkor növekedésével az elfogadás esélye 0,67 -szeresére csökken. A fiatalok pozitívabban látják a migrációt, mint a községben lakók, mivel az esély értéke náluk 2,33-szoros volt. A 2. faktor esetében - az integráció sikerességét mutatja a faktorértékek növekedésével - az elfogadás esélye is 2,8-szorosára nő. Ugyanez figyelhető meg kisebb mértékben a 4. faktor esetében („Bevándorlók megkülönböztethetősége”) is, mivel itt az esély 2,06-szoros volt. Az első faktor (,Veszélyérzet") esély értéke nagyon kicsi $(0,18)$, vagyis a faktor értékének növekedése a migráció veszélyének emelkedését mutatja, ezért az elfogadási hajlandóság ekkor jelentősen kisebb lesz. A harmadik faktornál („Hírforrások”) is 1 alatti az esély értéke, pontosan 0,631. Ennek magyarázata 
az lehet, hogy aki többet tájékozódik a médiából, kevésbé lesz elfogadó a migrációval kapcsolatban. Ez következhet abból, hogy ebben a témában nagyon sok negatív híradás volt Magyarországon az elmúlt időszakban.

\section{A migráció megítélését befolyásoló gazdasági okok}

A Hainmueller - Hiscox (2010) tanulmány két különálló módszerrel vizsgálta azt, hogy a gazdasággal kapcsolatos aggályok miként formálják a társadalom nézeteit és preferenciáit a migránsáradat megszüntetésére irányuló intézkedésekkel. Hipotézisünk szerint a bevándorlók megítélése elkülöníthető szakképzettségük szintje szerint. iskolai végzettséggel rendelkező válaszadók toleránsabbak és nyitottabbak a migránsokkal szemben, függetlenül azok szaktudásától. Összegezve megállapítható, hogy a magasan szakképzett külföldi munkaerő bevándorlását inkább támogatják a válaszadók - 3 pontátlag fölötti választ adtak - a képzettségi szint figyelembevétele nélkül. A válaszadó különböző szinten tanulmányokat folytató hallgatók közül a doktoranduszok nagyobb mértékben támogatják a bevándorlást a többi csoport tagjainál. Az alacsony képzettségü bevándorlók estében inkább elutasítóak a hallgatók a válaszadók 2 alatti pontátlaga alapján.

Hasonló módon vizsgáltuk a különböző jövedelmi szint alapján csoportosított válaszadók esetében, hogy miként

6. táblázat

A t-próba és varianciaanalízis eredményei a magas szakképzettségű bevándorlók esetében

\begin{tabular}{|c|c|c|c|c|c|c|}
\hline & & & szakkép & gü beván & & \\
\hline & Átlag & Szórás & F érték & p érték & t-érték & p érték \\
\hline Nő & 3,44 & 1,02 & 3,10 & 0,079 & $-3,49$ & 0,001 \\
\hline Férfi & 3,79 & 0,95 & & & & \\
\hline Vidék & 3,35 & 0,92 & 1,51 & 0,221 & $-3,69$ & 0,001 \\
\hline Város & 3,73 & 1,03 & & & & \\
\hline Munkanélküli & 3,57 & 1,03 & 3,41 & 0,066 & $-1,01$ & 0,311 \\
\hline Dolgozó & 3,71 & 0,87 & & & & \\
\hline Nem utazik külföldre & 3,56 & 1,02 & 2,98 & 0,085 & $-0,92$ & 0,360 \\
\hline Utazik külföldre & 3,67 & 0,96 & & & & \\
\hline Nincs családtagja külföldön & 3,40 & 1,06 & 4,12 & 0,043 & $-3,14$ & 0,002 \\
\hline Van családtagja külföldön & 3,72 & 0,94 & & & & \\
\hline Nincs külföldi barátja & 3,44 & 1,05 & 4,87 & 0,028 & $-2,89$ & 0,004 \\
\hline Van külföldi barátja & 3,73 & 0,94 & & & & \\
\hline Legmagasabb végzettsége (Érettségi) & 3,60 & 1,02 & 0,92 & 0,405 & & \\
\hline Legmagasabb végzettsége (BSc/BA) & 3,52 & 0,99 & & & & \\
\hline Legmagasabb végzettsége (MSc/MA) & 3,88 & 0,72 & & & & \\
\hline Jövedelemszint (Átlag alatt)" & 3,57 & 0,97 & 3,97 & 0,020 & $\mathrm{ab}$ & \\
\hline Jövedelemszint (Átlagos) & 3,50 & 1,01 & & & $\mathrm{a}$ & \\
\hline Jövedelemszint (Átlag felett) & 3,88 & 0,98 & & & $\mathrm{~b}$ & \\
\hline
\end{tabular}

* A Tukey post hoc teszt alapján szignifikáns különbség figyelhető meg 5\%-os hibaszinten. Az eltérő betűk statisztikai különbséget mutatnak az átlagok között. Az F-próba a szórások azonosságára, a t-próba az átlagok azonosságára vonatkozik.

Forrás: saját számítás, 2017

Külön bontva vizsgáltuk az alacsony és magas szakképzettségü bevándorlókkal kapcsolatos megítélést (6. és 7. táblázat). Megállapítható, hogy statisztikailag kimutathatóan fontosabbnak értékelték a magas végzettséggel rendelkező külföldi bevándorlókat a férfi, a városban élő, a külföldön élő családtag és a külföldi barát csoportjába tartozó válaszadókat. A doktori képzésben részt vevő hallgatók pozitívabban értékelték mind a magas, mind az alacsony szakmai képzettséggel rendelkező bevándorlók munkaerőpiacra gyakorolt hatását, átlagban 3,88, illetve 2,00 értéket mutatott a magas és alacsony képzettségüek bevándorlásának gazdasági haszna. A többi csoporttal összehasonlítva ez a különbség nem volt szignifikáns, ugyanakkor az a tendencia megvalósulni látszik, hogy a legmagasabb értékelik az alacsony, illetve magas szaktudással rendelkező emberek bevándorlását, továbbá mennyire tartanak attól, hogy a munkaerőpiacra beáramló külföldiek kiszoríthatják a hazai friss diplomásokat. Ezek az összehasonlítások és a megkérdezettek válaszainak karakterisztikája tette lehetővé, hogy közvetlenül prognosztizáljuk, miként befolyásolják a gazdasági tényezők a véleményalkotást (Hainmueller - Hiscox, 2010). A társadalmi osztályok szerint összesen három, nevezetesen átlag alatti, átlagos és átlag feletti gazdasági helyzetü csoportot képeztünk. Megállapítottuk, hogy az átlagtól magasabb társadalmi csoport statisztikailag kimutathatóan hasznosabbnak ítélte meg a magasan szakképzett külföldi munkavállalók gazdasági hasznosságát, ugyanis átlagosan 3,88-as értéket 
A t-próba és varianciaanalízis eredményei az alacsony szakképzettségű bevándorlók esetében

\begin{tabular}{|l|c|c|c|c|c|c|}
\hline \multirow{2}{*}{} & \multicolumn{5}{|c|}{ Alacsony szakképzettségú bevándorlók } \\
\cline { 2 - 6 } & Átlag & Szórás & F érték & p érték & t-érték & p érték \\
\hline Férfi & 1,69 & 0,77 & 2,76 & 0,097 & $-0,61$ & 0,543 \\
\hline Vidék & 1,74 & 0,89 & & & $-0,98$ & 0,330 \\
\hline Város & 1,66 & 0,83 & 0,04 & 0,835 & & \\
\hline Munkanélküli & 1,74 & 0,82 & & & $-1,07$ & 0,287 \\
\hline Dolgozó & 1,69 & 0,82 & 0,02 & 0,897 & & \\
\hline Nem utazik külföldre & 1,81 & 0,88 & & & & \\
\hline Utazik külföldre & 1,75 & 0,85 & 1,37 & 0,243 & & \\
\hline Nincs családtagja külföldön & 1,55 & 0,74 & & & & 0,040 \\
\hline Van családtagja külföldön & 1,75 & 0,87 & 2,27 & 0,133 & 0,375 \\
\hline Nincs külföldi barátja & 1,68 & 0,79 & & & & $-0,71$ \\
\hline Van külföldi barátja & 1,68 & 0,78 & 1,38 & 0,241 & 0,479 \\
\hline Legmagasabb végzettség (Érettségi) & 1,73 & 0,83 & 2,02 & 0,133 & & \\
\hline Legmagasabb végzettség (BSc/BA) & 1,60 & 0,78 & & & & \\
\hline Legmagasabb végzettség (MSc/MA) & 2,00 & 0,89 & & & & \\
\hline Jövedelemszint (Átlag alatt)* & 1,89 & 0,87 & 2,63 & 0,074 & & \\
\hline Jövedelemszint (Átlagos) & 1,67 & 0,83 & & & & \\
\hline Jövedelemszint (Átlag felett) & 1,64 & 0,75 & & & \\
\hline
\end{tabular}

* A Tukey post hoc teszt alapján szignifikáns különbség figyelhető meg 5\%-os hibaszinten.

Az F-próba a szórások azonosságára, a t-próba az átlagok azonosságára vonatkozik.

Forrás: saját számítás, 2017

adtak a minőségi sorrendet alkotó Likert-skálán (a Likert a skála 1-es értéke a „teljes mértékben káros”, 5-ös értéke a „teljes mértékben hasznos” értékelést jelenti). Ezzel szemben az alacsony szakképzettségúek gazdasági hasznának értékelésénél az átlagosnál alacsonyabb jövedelemmel rendelkező csoport a legelfogadóbb.

A szociális ellátórendszerre nehezedő rövid és hosszú távú nyomás szerepe nem állapítható meg egyértelműen, mert nem világos, hogy az átlag fölötti társadalmi csoportba tartozó tagok azért utasítanák el az alacsony szakképzettségűek bevándorlását, mert az általuk igénybe vett támogatások miatt növekedne a magasabb jövedelmüek adófizetési kötelezettsége, kiemelten a jövedelmi alapon differenciált, többkulcsos adórendszert működtető országok lakossága esetében. Hainmueller - Hiscox (2010) tanulmányában kitért ugyan arra, hogy a bevándorlók a munkaerőpiacra lépésig és azt követő rövid időszakban megfigyelhetően jobban függenek a támogatásokat nyújtó programoktól, de abban nincs egyetértés, hogy az igy felmerülö kihívások kezelésére az állam egyetlen eszköze az adónövelés lenne. Azt is szem elött kell tartani, hogy az Európai Unió tagállamainak társadalmában demográfiai öregedés figyelhető meg, így a fiatal bevándorló munkaerő hosszabb távon nem a szociális ellátórendszert veszi igénybe, hanem ezzel szemben hozzájárul az ellátórendszer bevételéhez, tehát ezzel pozitív fiskális hatást eredményez. Az alacsonyabb jövedelemmel rendelkező csoportok esetében mért nagyobb elfogadás az alacsony szakképzettségüek befogadásával összefüggésben szintén ellentmondásossá teszi azt a kijelentést, miszerint a bevándorlás elleni általános hangulat meghatározó oka lenne a tagállam szociális ellátórendszerének túlzott megterhelése (European Commission, 2017).

\section{A sajtó hatásának felmérése a migránsok befogadásával kapcsolatos vélemények kialakítása során}

A sajtó kulcsszerepet játszhat abban, hogy a migrációról egy valósághü és objektív kép alakuljon ki a magyar társadalomban (Gyulai, 2011).

A felmérés során a válaszadóktól megkérdeztük, hogy milyen gyakran tájékozódnak a világban zajló migrációs helyzetről. A nagyobb sajtótermékeket az alábbi típusokba soroltuk:
A. közszolgálati televízió-, rádióadás,
B. kereskedelmi televízió-, rádióadás,
C. külföldi média,
D. internetes szaksajtó,
E. internetes közösségi oldal.

A megkérdezettek többsége a híradásokból és különböző beszámolókból időnként követi a migráció folyamatait és az ezzel kapcsolatos eseményeket (1. ábra). Kiemelést érdemel, hogy a magyar felsőoktatásban a hallgatók több mint egynegyede egyáltalán nem tájékozódik külföldi 
forrásból, kizárólag a magyar nyelvü híradásokat követi. Egyértelmű továbbá az online média dominanciája a technológiai fejlődésének és a fiatal átlagéletkornak köszönhetően.

\section{Milyen gyakran követi a migrációval kapcsolatos} híreket a következő sajtótermékekből?

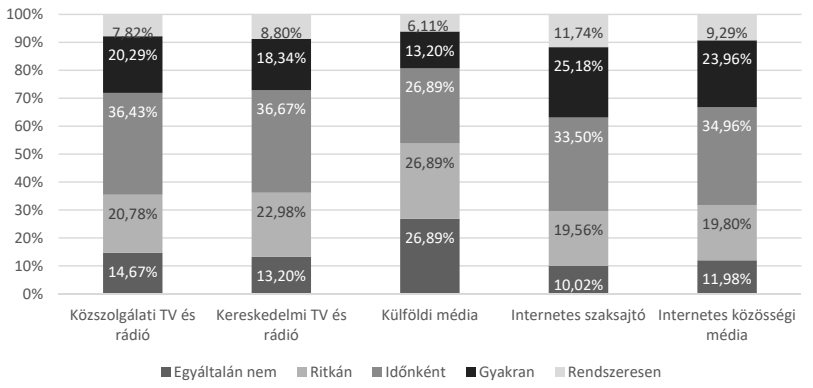

Forrás: saját ábra, 2017 galmának helyes meghatározását az 1951-es Genfi Egyezmény értelmében. A válaszadók jelentős hányada, 76,5\%a helytelen meghatározást választott ki, de kiemelendő, hogy a sajtó által közölt információk rendszeres követése javuló tendenciát mutatott a fogalmi ismeretek terén.

Az internetes szaklapok - szaksajtó - és a közösségi média iránt tanúsított nagyobb érdeklődés miatt azt is vizsgáltuk, hogy az összes gyakorisági kategóriát alapul véve van-e összefüggés a helyes fogalmi ismeretek és a magyar hallgatók tájékozódottsága között. A hagyományos források esetében 18,5\% - 21,7\% közötti arányban adtak helyes választ azok, akik bevallásuk szerint egyáltalán nem követik a migráció híreit. Ezzel szemben 40,6\% - 47,2\% arányban ismerték a menekült fogalmi meghatározását azok a válaszadók, akik rendszeresen olvassák és hallgatják a bevándorlással kapcsolatos információkat. Ez azért is fontos szempont, mert a pontos fogalmi ismeretek esetében a bevándorlást inkább elutasítóan, míg a menekültek befogadását inkább támogatóan értékelték (8. táblázat). A felmérésben megkérdeztük, hogy a válaszadók

8. táblázat

Két független mintás t-próba a menekültek és bevándorlók támogatottságának vizsgálatára a menekültek fogalmát helyesen ismerők és nem ismerők között

\begin{tabular}{|c|c|c|c|c|c|c|c|}
\hline & \multicolumn{2}{|c|}{$\begin{array}{c}\text { Levene-próba szórásho- } \\
\text { mogenitás feltétele }\end{array}$} & \multicolumn{4}{|c|}{ t-próba } \\
\cline { 2 - 8 } & F érték & p érték & t-érték & Szf & p érték & $\begin{array}{c}\text { Átlagok } \\
\text { különbsége }\end{array}$ & $\begin{array}{c}\text { A különbség } \\
\text { standard } \\
\text { hibája }\end{array}$ \\
\hline $\begin{array}{c}\text { Menekültek } \\
\text { támogatása }\end{array}$ & 1,27 & 0,261 & 1,19 & 406 & 0,237 & 0,16 & 0,13 \\
\hline $\begin{array}{c}\text { Bevándorlók } \\
\text { támogatása }\end{array}$ & 1,06 & 0,304 & $-4,33$ & 407 & $<0,001$ & $-0,53$ & 0,12 \\
\hline
\end{tabular}

Forrás: saját számítás, 2017

Két független mintás t-próba az ismeretek és hírforrások vizsgálatára a menekültek fogalmát helyesen ismerők és nem ismerők között

\begin{tabular}{|c|c|c|c|c|c|c|c|}
\hline & \multicolumn{2}{|c|}{$\begin{array}{l}\text { Levene-próba szórásho- } \\
\text { mogenitás feltétele }\end{array}$} & \multicolumn{5}{|c|}{ t-próba } \\
\hline & F érték & p érték & t érték & Szf & p érték & $\begin{array}{c}\text { Átlagok } \\
\text { különbsége }\end{array}$ & $\begin{array}{c}\text { A különbség } \\
\text { standard } \\
\text { hibája }\end{array}$ \\
\hline Közszolgálati TV, rádió & 0,60 & 0,439 & 2,43 & 410 & 0,016 & 0,32 & 0,13 \\
\hline $\begin{array}{c}\text { Kereskedelmi TV, } \\
\text { rádió }\end{array}$ & 1,71 & 0,191 & 3,12 & 415 & 0,002 & 0,40 & 0,13 \\
\hline Külföldi média & 2,00 & 0,158 & 2,33 & 414 & 0,020 & 0,32 & 0,14 \\
\hline Internetes szaksajtó & 2,68 & 0,102 & 2,14 & 414 & 0,033 & 0,28 & 0,13 \\
\hline $\begin{array}{c}\text { Internetes közösségi } \\
\text { média }\end{array}$ & 17,21 & $<0,001$ & 0,85 & 134 & 0,397 & 0,13 & 0,15 \\
\hline
\end{tabular}

Forrás: saját számítás, 2017

A kérdőíven keresztül azt is felmértük, hogy a válaszadók mennyire vannak tisztában az egyes jogi szabályozásokkal és definíciókkal. Ellenőrző kérdésként szerepelt, hogy három eltérő definíció közül válasszák ki a menekült fo- mennyire elfogadó álláspontot képviselnek a háború elől menekülők befogadásával kapcsolatban. Az eredmények azt mutatják, hogy az elfogadás mértékének átlaga a definíciót nem ismerő válaszadók esetében nem különbözött 
azok válaszának átlagától, akik ismerték az EU szabályozásait. Ugyanakkor a gazdasági bevándorlók esetében már szignifikáns különbség volt megfigyelhető abban, hogy mennyire értékelik pozitívan a migrációt a témával összefüggő tudásuk függvényében (Gyulai, 2011).

Az ismertetett két független mintás t-próba alapján kiderült, hogy az internetes közösségi média esetében szignifikáns a Levene-próba, azaz szignifikáns különbség van a helyes és helytelen válaszadók csoportjának szórásaiban (9. táblázat). Ezért a Welch-féle d-próbát alkalmaztuk, amely eredménye szerint nincs szignifikáns különbség a menekültekre vonatkozó fogalmi definíciót ismerők és nem ismerők átlagában annak függvényében, hogy milyen rendszeresen követik a közösségi médiát. Összefoglalva tehát megállapítható, hogy ennek a hírközlési platformnak nincs jelentős szerepe a bevándorlással kapcsolatos hasznos ismeretek megszerzésében. A közösségi oldalakon megjelenő hírek, illetve cikkek gyakorta félretájékoztatják a felhasználókat, így ezek szürésére az egyik legismertebb közösségi weboldal - a Facebook - is kiemelt figyelmet fordít (Forbes, 2017).

\section{Következtetések és javaslatok}

A H1 hipotézisben megfogalmazottak további három feltételezést vetítettek elő. Az „A” részben az a megállapítás dőlt meg, amely szerint a válaszadók iskolai végzettsége és a bevándorló munkaerő szakképzettsége közötti kapcsolat értelmezése a munkaerőpiacra nehezedő nyomással magyarázná a társadalom migrációellenességét. A feltáró faktoranalízis során hasonlóan ellentmondásosnak bizonyult az a „B” feltételezés, hogy a hazai lakosság eltérő társadalmi osztályai és ezek különböző jövedelemszintjei eltérően ítélik meg azt, hogy a különböző szakképzettséggel rendelkező külföldi munkavállalók milyen hatással vannak a magyar munkaerö-piaci versenyre, hiszen szignifikáns összefüggés nem volt tapasztalható. Végül a „C” feltételezés is megdőlt, amely szerint az egyéni döntéseket az is meghatározza, hogy a válaszadók mennyire ítélik veszélyesnek a bevándorlás a gazdaság és szociális ellátórendszere gyakorolt hatását hosszú távon.

A H2 hipotézis értelmében beigazolódott, hogy a felmérésben megkérdezettek valójában a kulturális identitásuk megőrzése és a társadalmi kohézió fenntartása érdekében állnak elutasítóan a migrációhoz. A nyelvi akadályok és az integráció meghiúsulása további problémák forrását jelenti. Végül a média szerepe is középpontba került, sőt a H3 hipotézisben megfogalmazott megítélésre vonatkozó hatások valóban megfigyelhetők voltak. A megbízható források elősegítették az eseményekkel kapcsolatos információáramlást, ugyanakkor ezzel szemben a megbízhatatlan, gyakran téves források szintén befolyásolták a válaszadók megítélését, ellenkező hatást kiváltva. A közösségi média esetében szignifikáns eredmény nem volt mérhető, ugyanakkor e platformon terjedö hírek gyakran félrevezetőek, így felügyeletük a társadalom egészének érdekét képviseli.

Nemzetközi szinten is fontos felhívni a figyelmet a migráció súlyos, globális problémájára, továbbá közös összefogással, egymás segítésével célszerű megkeresni a megfelelő megoldást minden érintett szempontjából.

\section{Felhasznált irodalom}

Bauer, T. K. - Lofstrom, M. - Zimmerman. K. F. (2000): Immigration Policy, Assimilation of Immigrants, and Natives' Sentiments towards Immigrants: Evidence from 12 OECD-Countries. IZA Discussion Paper. No. 187. Institute for the Study of Labor (IZA)

Bogáromi E. - Malota E. (2017): Kulturális sokk és fogyasztói akkulturáció - kétirányú, interdiszciplináris megközelítésben. Vezetéstudomány, Vol. 48, No. 4, p. 6-17.

Braun, K. (2017): Decolonial Perspectiveson Charitable Spaces of "Welcome Culture" in Germany. Social Inclusion, Vol. 5. No. 3, p. 38-48.

Citrin, J. D. P. - Green, C. M. - Wong, C. (1997): Public Opinion towards Immigration Reform: The Role of Economic Motivations. Journal of Politics, Vol. 59. p. 858-881.

Ekéné Zamárdi I. - Dövényi Z. (2010): Migráció és mobilitás. In: Tóth J. (szerk.): Világföldrajz. Budapest: Akadémiai Kiadó, p. 376-405.

European Commission (2008): EUROBAROMETER 69 1. Values of Europeans. http://ec.europa.eu/public_opinion/archives/eb/eb69/eb69_values_en.pdf, letöltés dátuma: 2017. 04. 05

European Commission (2016): An Economic Take on the Refugee Crisis - A Macroeconomic Assessment for the EU. Institutional Paper 033/2016. p. 7-32.

European Commission - Immigration Portal (EUIP) (2017): Coming to the EU. http://ec.europa.eu/immigration/who-does-what/what-does-the-eu-do/comingto-the-eu_en, letöltés dátuma: 2016. 11. 13.

Facchini, G. - Mayda. A. (2009): Does the Welfare State Affect Individual Attitudes toward Immigrants? Evidence across Countries. Review of Economics and Statistics, Vol. 91, No. 2, p. 295-314.

Field, A. (2013). Discovering Statistics Using SPSS. (4th Edition). London: SAGE Publication, University of Sussex

Forbes (2017): Federico Guerrini - Facebook Will Flag and Filter Fake News in Germany, https://www.forbes. com/sites/federicoguerrini/2017/01/16/facebook-willflag-and-filter-fake-news-in-germany/\#15702fdc3bb7, letöltés dátuma: 2017. 0316.

Gödri I. (2016): A bevándorlók munkaerőpiaci integrációja Magyarországon - népszámlálási helyzetkép. In: Blaskó Zs. - Fazekas K.: Munkaeröpiaci tükör 2015. Budapest: MTA Közgazdaság- és Regionális Tudományi Kutatóközpont Közgazdaságtudományi Intézet, p. 121-134.

Gyulai G. (2011): Külföldiek Magyarországon: Segédlet újságíróknak a migráció és a menekültügy témájának bemutatásához. Európai Integrációs Alap, Magyar Helsinki Bizottság. http://helsinki.hu/wp-content/uploads/Kulfoldiek-Magyarorszagon-05-11-2011-WEB. pdf, letöltés dátuma: 2017. 03. 17. 
Hainmueller, J. - Hiscox, M.J. (2010): Attitudes toward highly skilled and low-skilled immigration: Evidence from a survey experiment. American Political Science Review, Vol. 104, No. 1, p. 61-84.

Hautzinger, Z. - Hegedüs, J. - Klenner, Z. (2014): A migráció elmélete. Nemzeti Közszolgálati Egyetem Rendészettudományi Kar. Budapest: Nemzeti Közszolgálati és Tankönyv Kiadó Zrt.

Hooghe, M. - Trappers, A. - Meuleman, B. - Reeskens, T. (2008): Migration to European Countries. A Structural Explanation of Patterns, 1980-2004. International Migration Review, Vol. 42 No. 2, p. 476-504.

Hubert J. (2017): Adománygyüjtés, impulzusadományozás a közösségi médiában. Vezetéstudomány, Vol. 48. No. 2, p. 67-78.

Index (2017). Forrás: http://index.hu/aktak/ Utolsó letöltés dátuma: 2017. október 24.

Janky B. (2016): A témakeretezés hatása a menekültpolitikával kapcsolatos véleményekre. REGIO, Vol. 24. No. 4, p. 121-139.

Kiss E. (2016): "The Hungarians Have Decided: They Do Not Want Illegal Migrants" Media Representation of the Hungarian Governmental Anti-Immigration Campaign. Acta Humana, Vol. 4, No. 6, p. 45-77.

Központi Statisztikai Hivatal (2017a): Városi lakosság aránya. http://demografia.hu/hu/tudastar/fogalomtar/84-varosi-lakossag-aranya, letöltés dátuma: 2017. 01. 10.

Központi Statisztikai Hivatal (2017b): Visszatekintő adatok. http://www.ksh.hu/nepszamlalas/tablak_iskolazottsag, letöltés dátuma: 2017. 01. 10.

Központi Statisztikai Hivatal (2017c): Oktatás (1960-) 2. http://www.ksh.hu/docs/hun/xstadat/xstadat_hoszszu/h_wdsi001b.html, letöltés dátuma: 2017. 01. 10.

Kránitz $\bar{P}$. P. (2016): Menekült vagy migráns? REGIO, Vol. 24, No. 3, p. 59-81.

Lahav, G. (2004): Immigration and Politics in the New Europe. Cambridge: Cambridge University Press
Lajos V. (2016): Migránsvilágok, jótékonykodás és gyakorlati alkalmazás. Lehetséges kulcskérdések a kortárs migrációs folyamatok kutatásában. Menekültek, migránsok, új hazát keresők. 25. Debrecen: Debreceni Egyetem Történelmi Intézete

Máté D. - Sarihasan, I. - Dajnoki K. (2017): The Relations between Labour Market Institutions and Employment of Migrants. Amfiteatru Economic, Vol. 19, No. 46, p. 806-820.

Nagy B. - Primecz H. (2014): Hard choices. In: Hutchings, K. - Michailova, S. (szerk.): Research handbook on women in international management. Cheltenham, Northampton: Edward Elgar Publishing, p. 246-275.

Oláh J. - Halasi Gy. - Szakály Z. - Popp J. - Balogh P. (2017): The impact of international migration on the labor market - A case study from Hungary. Amfiteatru Economic, Vol. 19, No. 46, p. 790-805

Pop, N.A. - Pelau, C. (2017): Correlations within the EFQM Business Excellence Model by Applying a Factor Analysis. Amfiteatru Economic, Vol. 19, No. 44, p. 28-40.

Savov, R. - Chebeň, J. - Lančarič, D. - Serenčéš, R. (2017): MBNQA Approach in Quality Management Supporting Sustainable Business Performance in Agribusiness. Amfiteatru Economic, Vol. 19, No. 44, p. 10-27.

Schiller, N.G. - Basch, L. - Blanc-Szanton, C. (1992): Transnationalism: A new analytic framework for understanding migration. Annals of the New York Academy of Sciences, Vol. 645, No. 1, p. 1-24.

Szabó A. (2015): Az egyetemisták és főiskolások Magyarországon. Szeged: Belvedere Meridionale

Tóth J. (2015): Mozgó-képek: szisztematikus áttekintés a muszlimok médiareprezentációjáról kortárs szociológiai kutatásokban. Információs Társadalom, Vol. No. 3, p. $18-40$.

Vág A. (2010): A környezeti migráció okai. Tér és Társadalom, Vol. 25, No. 3, p. 59-74. 